\title{
Bioelectricity from Anaerobic Co-Digestion of Organic Solid Wastes and Sewage Sludge Using Microbial Fuel Cells (MFCs)
}

\author{
Rasel Sheikh*, Sourav Karmaker, Mohammad Solayman, Jebunnahar Mayna \\ Department of Disaster Resilience and Engineering, Faculty of Disaster Management, Patuakhali Science and Technology \\ University, Dumki Upazila, Bangladesh \\ Email: *raselsheikh55@gmail.com
}

How to cite this paper: Sheikh, R., Karmaker, S., Solayman, M. and Mayna, J. (2018) Bioelectricity from Anaerobic Co-Digestion of Organic Solid Wastes and Sewage Sludge Using Microbial Fuel Cells (MFCs). Journal of Sustainable Bioenergy Systems, 8, 95-106. https://doi.org/10.4236/jsbs.2018.83007

Received: June 14, 2018

Accepted: September 24, 2018

Published: September 27, 2018

Copyright (c) 2018 by authors and Scientific Research Publishing Inc. This work is licensed under the Creative Commons Attribution International License (CC BY 4.0).

http://creativecommons.org/licenses/by/4.0/

\begin{abstract}
Recently microbial fuel cells (MFCs) have been considered as an alternative power generation technique by utilizing organic wastes. In this study, an experiment was carried out to generate bioelectricity from co-digestion of organic waste (kitchen waste) and sewage sludge as a waste management option using microbial fuel cell (MFC) in anaerobic process. A total of five samples with different sludge-waste ratio were used with zinc $(\mathrm{Zn})$ and cupper $(\mathrm{Cu})$ as cell electrodes for the test. The trends of voltage generation were different for each sample in cells such as $350 \mathrm{mV}, 263 \mathrm{mV}, 416 \mathrm{mV}$ maximum voltage were measured from sample I, II and III respectively. It was observed that the MFC with sewage sludge showed the higher values (around $960 \mathrm{mV}$ ) of voltages with time whereas $918 \mathrm{mV}$ obtained with organic waste. Precisely comparing cases with varying the organic waste and sewage sludge ratio helps to find the best bioelectricity generation option. Using MFCs can be appeared as the solution of electricity scarcity along the world as an efficient and eco-friendly manner as well as organic solid waste and sewage sludge management.
\end{abstract}

\section{Keywords}

Bioelectricity, MFC, Organic Waste, Sewage Sludge, Anaerobic Co-Digestion

\section{Introduction}

The present world still is in serious power crisis and looking for resource recovery from various used materials like organic wastes. About $17 \%$ of 1.3 billion people in the Asian country live without access of electricity. Figure 1 describes some Asian country where still without access of power. More than $67 \%$ people 
of North Korea, Burma and Cambodia are mostly suffering due to in access of power supply. Consequently, power scarcity and sudden failure of electricity are very natural event that are creating difficulties for the inhabitants of the emerging countries, particularly at night time [1]. In this context, search of alternative power source like organic waste resource recovery is an important topic [2].

Rapid growing of urbanization and industrialization produces million tons of organic wastes every day threating the entire world in this century. Management of this huge amount of waste is concerning issues these days though there is no planned waste management system in developing countries in the Asian region. But Moqsud (2003) [3], Zurbrugg et al. (2005) [4] and Sajuddinn and Hoque (2008) [5] reported that, recycled compost of the organic part of wastes can be an effective power source. In addition, the organic waste comprises big amount of nutrients and other minerals.

Nowadays resource recovery has become very important and very attractive because of the growing need for alternative power demand while the amount of non-renewable fuel is being consumed rapidly. Mostafa et al. (2011) [6] reported, fuel cells (FC) technology can be used to produce electricity as renewable energy sources. Moqsud et al. (2013) [7] also investigated the use of microbial fuel cells (MFCs) to change microbial reducing energy into electrical energy. Microbial fuel cells produce electricity as well as anaerobic decomposition creates compost which is the well-known waste recycling process. There has been already some research work on microbial fuel cells to produce bioelectricity from light energy, organic waste and electro-catalysis in MFCs [7] [8] [9].

It is also a substitute process of generating electricity by using various type of waste (organic waste, industrial waste, sewage sludge etc.) for small scale use. Organic and chemical toxic wastes are processed by rapid microbial decomposition at relatively anaerobic digestion by which microorganisms break down biodegradable material in the absence of oxygen [10]. In the cell, the interaction of microorganisms with electrodes has been held using electrons, which flows through an electrical circuit.

However, higher power generation options and electron transfer process which accelerates the microbial activities in MFCs through the blend of organic solid waste and sewage sludge. In this experiment, advantages of the anaerobic co-digestion process used as microorganisms consumes the substrate like organic wastes in an anaerobic condition they produce carbon di-oxide, protons and electrons as represents in a diagram (Figure 2) [11].

Organic waste and sewage sludge composite digested by the microorganisms when living on the composite and take it as nutrition, the composite breaking free with negative charge electrons (e-) which occupied by the anode plate and flow with a circuit to the cathode plate, which means it produces the electricity with the help of tiny microorganisms.

Kannaiah et al. (2011) [12] express that the power generation increases at substrate loading conditions and combined action of anaerobic fermentation and 
electrochemical process evidenced the higher efficiency than conventional treatment process. Recently, it has been realized that anaerobic digestion as such became more stable when the variety of substrates applied at the same time is increased [13]. However, an anaerobic condition has been investigated mixing organic waste and sewage sludge for power generation. The main objectives of the study are to generate bioelectricity through the anaerobic co-digestion of organic solid wastes and sewage sludge using a one-chambered microbial fuel cell and to evaluate the best way of resource recovery and environment friendly solution of organic solid wastes and sewage sludge management.

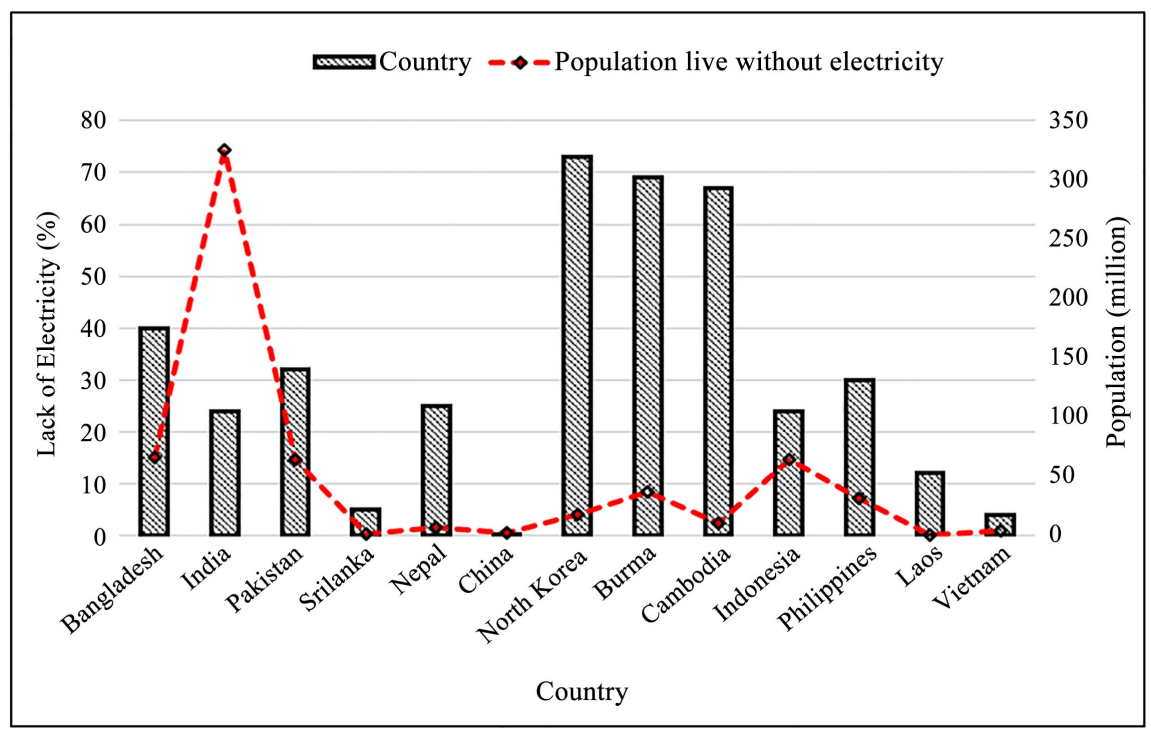

Figure 1. Region in the Asia where still in no Electricity. (Source: Reprocessed from: https://www.washingtonpost.com/graphics/world/world-without-power/?noredirect=on).

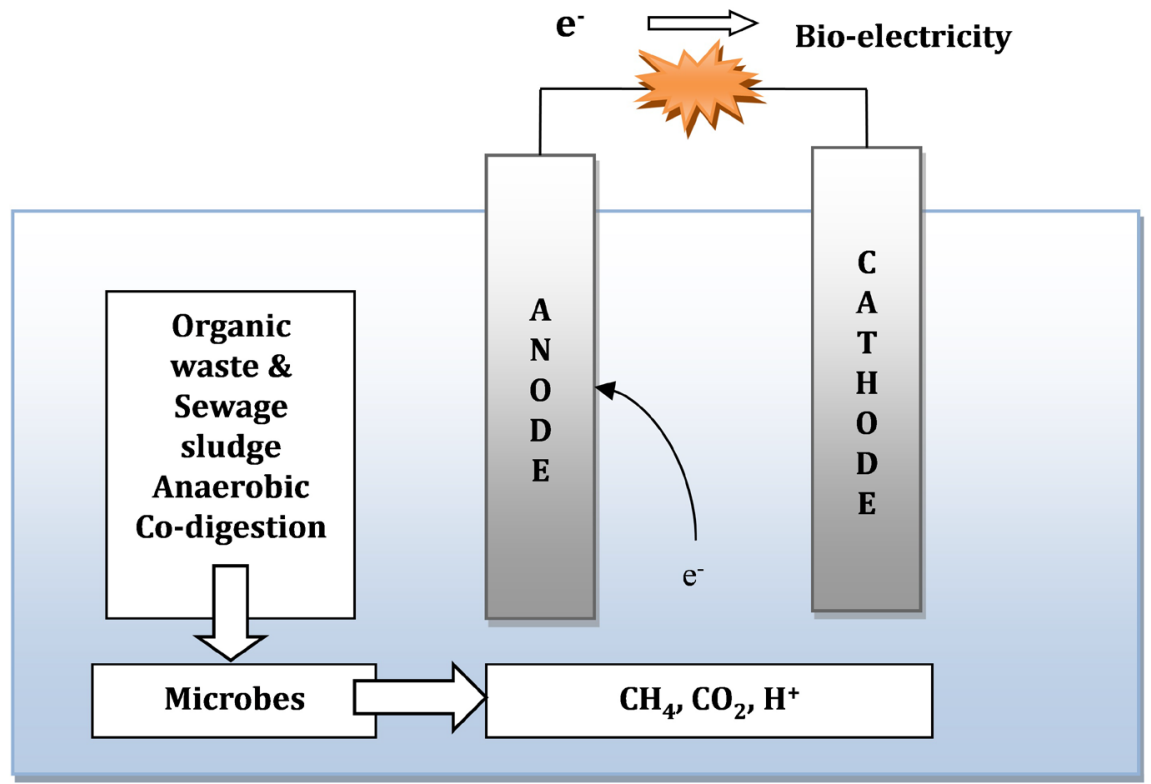

Figure 2. Electro genesis process from MFC in anaerobic condition. 


\section{Materials and Methods}

\subsection{Experimental Materials and Laboratory Instruments}

The experiments were carried out in the Department of Disaster Resilience and Engineering (DRE) of Patuakhali Science and Technology University (PSTU), Bangladesh and the materials used in this study were prepared such as Zinc and Copper plate for electrode, connecting copper wire, vegetable wastes, multi-meter, resistors and other supporting equipment for test.

The sewage sludge which used in this study was collected from sewerage drain of PSTU $\left(22.4661^{\circ} \mathrm{N}\right.$ and $\left.90.3824^{\circ} \mathrm{E}\right)$. A $120 \Omega$ LED light was used in this research as load resistor to get potential difference in volts (V) unit. To measure potential difference directly in voltage unit, a SENIT-VC890D + model multimeter was used as this device can measure direct current up to micrometer range digitally. The advantages of using zinc and copper plate as electrode were sufficient sites for the electron transfer reaction and their suitability for good production with simplicity.

\subsection{Assembly of One-Chambered MFC}

In this experiment, MFCs were applied to generate power as voltage unit from the co-digestion of organic waste (kitchen waste) and sewage sludge over a testing duration 60 day. Figure 3 illustrates the schematic diagram of one-chambered MFC used in this study. 20-liter plastic bucket ( $476 \mathrm{gm}$ ) with diameter of $30 \mathrm{~cm}$ and total height of $40 \mathrm{~cm}$ ( $8 \mathrm{~cm}$ freeboard) used as an MFC container in the DRE laboratory at PSTU campus. Then, different ratio of organic waste and sewage sludge were added to the plastic container (MFC) and vigorous stirring were done for complete mixing. The moisture content of both organic waste and sewage sludge were determined by gravimetric procedure of weighing the samples before and after the water was removed. $20 \mathrm{~cm} \times 5 \mathrm{~cm} \times 0.1 \mathrm{~cm}$ size zinc $(\mathrm{Zn})$ and copper $(\mathrm{Cu})$ plates were used as anode $(-)$ and cathode $(+)$ respectively. Both electrodes were placed vertically $18 \mathrm{~cm}$ downward from the top surface of the compost mix. With a single copper wire, a connection was made in series to anode and cathode with a fixed external capacitor and LED bulb as load resistance $(120 \Omega)$ for the electricity being produced which measured by using multi-meter in daily basis. The anaerobic conditions were assured by covered the MFC container and sealed it with M-seal glue. In this experiment, no proton exchange membrane was used as mediator to observe electron flow directly. To ensure the power generation variety in this study, the experiments were conducted with pure samples and mixed samples. In the compartment of MFC device, the generalized chemical reaction for the anaerobic decomposition of organic waste and sewage sludge can be written as:

$$
\begin{aligned}
\text { Organic Matter }+\mathrm{H}_{2} \mathrm{O} \rightarrow & \text { Biodegradable Organic Matter }+\mathrm{CH}_{4} \\
& +\mathrm{CO}_{2}+\text { Other gases }
\end{aligned}
$$

When the microbial activity has begun by the breakdown of organic matter, it sets the electrons free which produces electricity. The laboratory investigations 


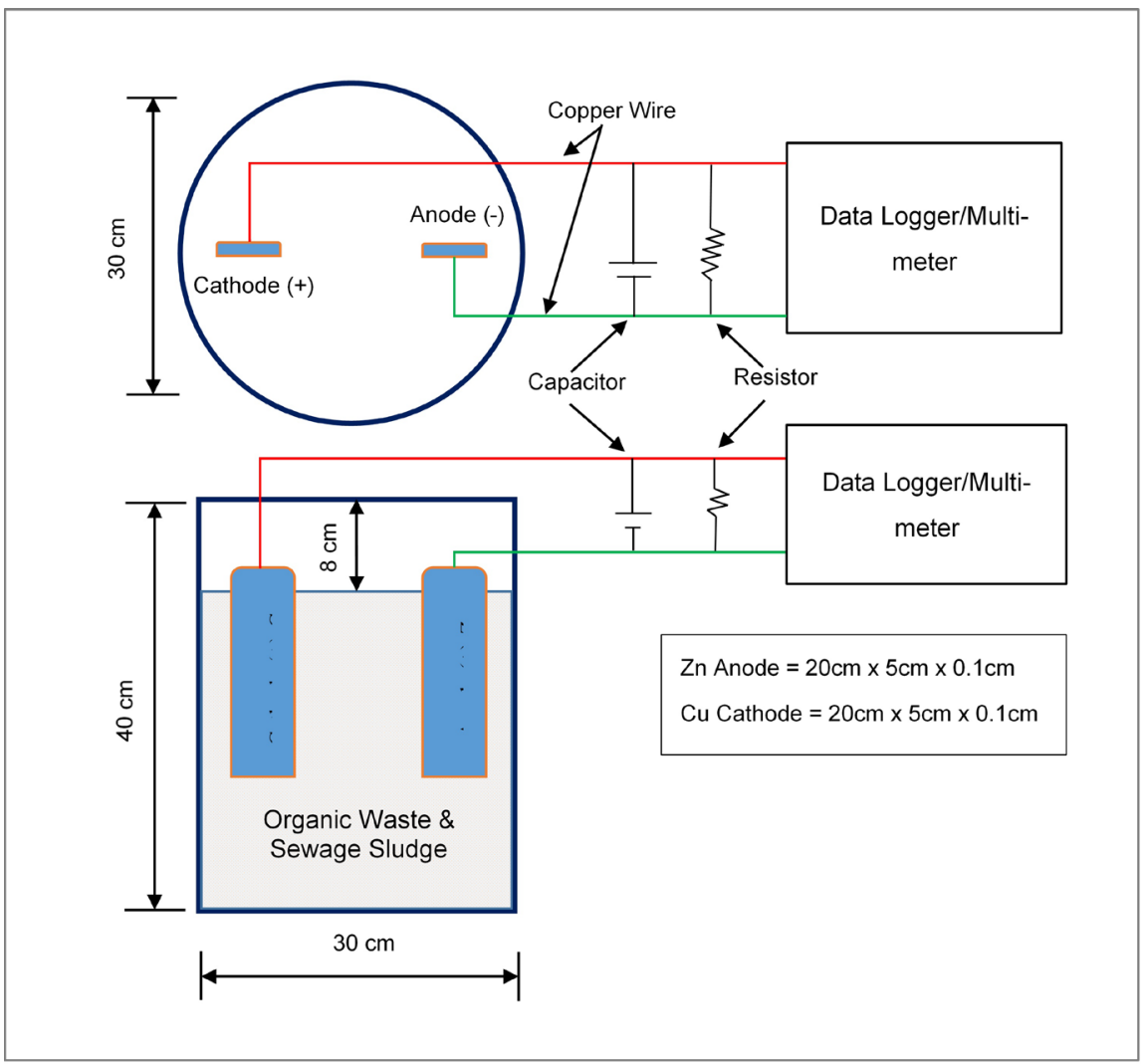

Figure 3. The schematic diagram of the MFC used in this study.

were conducted in room temperature varying in range $27^{\circ} \mathrm{C}$ to $31^{\circ} \mathrm{C}$, reported humidity was $73 \%-75 \%$.

Power generation in an MFC was affected by many significant parameters including bioreactor system configuration, type of microorganisms, organic substrates or biomass fuel categories, concentration, ionic strength, $\mathrm{pH}$ and temperature etc. The operation of the microbial fuel cell was monitored in a same time of the day and listed the voltage output in a voltage generation chart. Total three repetitions of each treatment were made, and finally average values of voltage generation were reported.

\subsection{Experimental Samples of the MFCs}

To fulfil the objectives, two types of the MFCs samples were prepared to investigate the generated voltage variation using different amount of waste and sludge ratio at the same volume. Quanguo et al. (2016) [14] reported that the conversion of chemical energy in influent substances to electricity via biological degradation can be done by using MFC as there are many microorganisms in the sewage sludge. So, it was considered that more voltage generation can be done by mixing sewage sludge with organic waste in an anaerobic co-digestion. Moreover, the mixed sewage sludge and some of organic waste in this experiment as they are thought to increase the physical volume of samples properties and it increases the nutrient supply ability for microorganism [2]. The type and number 
of microorganisms which survive are different by region in the distribution of the sewage sludge mass. The mixture of organic constituents in the waste and microorganisms in the sewage sludge are expected to generate the higher values of voltage output. The cells were prepared as the same way described in Figure 1 except the ratios of organic waste and sewage sludge. Table 1 is representing both pure samples and mixed samples parameter conditions used in this study. Sample I, II and III represent the mixed samples with different sludge/waste ratio whereas sample IV and V represent pure samples. $10 \mathrm{~kg}$ of kitchen waste and $10 \mathrm{~kg}$ of sewage sludge were taken as both pure sample IV and Sample V respectively. The moisture contents and $\mathrm{pH}$ of kitchen wastes and sewage sludge were tested in the laboratory as presented in Table 1 as these two properties affect much on the production of electricity and microbial activity as well.

\subsection{Monitoring and Data Measurement}

It is generally well known that MFC is the direct current (DC) source and in this experiment the value of potential difference (voltage) between anode and cathode was measured. Monitoring of the cells was completed on daily at 11:00 am and the readings of the voltage outputs recorded in a voltage generation chart. Multi-meter was used to measure the readings of voltage generation which represented by volts $(\mathrm{V})$. This process of data acquisition continued until the lowest voltage reading by the MFC. The values of voltage generated have shown are the average of three consequent tests with same parameter conditions.

Power output of the MFC cell was calculated in volts $(\mathrm{V})$ against time ( $t)$. Using Ohm's law, the current density I in amperes (A) unit was calculated

$$
I=V / R
$$

where $V$ is the measured potential difference in volts $(\mathrm{V})$ and $\mathrm{R}$ is the known value of the fixed load resistor in Ohms (120 $\Omega$ LED light used in this study). Now, it was possible to find the power output P in watts (W) of the MFCs by taking the multiplication of the voltage output and current densities i.e.

$$
P=I \times V
$$

Generally, the anode and cathode area are taken as the electrode area. In this experiment, both electrodes have selected as rectangular in size so that the total area can be calculated by multiplication of length and width.

\section{Results and Discussion}

\subsection{Bioelectricity from Mixed Samples}

Figure 4 illustrates the variation of voltage output with duration by using organic solid waste and sewage sludge in MFCs. In case of the mixed sample I, voltage $(V)$ were not increased sharply during the initial time (6 days); after that, it has increased gradually and peaked after 27 days. It has happened because of initial time; the bacteria take time to grow and degrade the mixture of sewage sludge and organic waste and at that time owing to the presence of air inside the 
sample materials. In the meantime, the microorganisms got ample food and their activities increased and for the prevalence of anaerobic conditions the voltage output of the sample increases very rapidly [2]. At 28th day, the voltages were started to decrease gradually with time as the supply of food was used up by the bacteria. Peak voltage of this sample was around $350 \mathrm{mV}$ using the ratio 1:2 of sewage sludge and organic waste in anaerobic condition with the total weight of the mixture $10 \mathrm{~kg}$. This voltage reading was taken until it stopped showing a better output. Over 60 days reading of voltages were taken and on 60th day this sample shows around voltage rate $111 \mathrm{mV}$.

The mixed sample II was kept 4 days aside to start over the activities of the microorganisms to degrade the organic wastes and sewage sludge. The voltage was increased sharply within the second day of the operation of the microbial fuel cell. It increased gradually and peaked after 21 days of $263 \mathrm{mV}$ which has been showed with the doted-triangle line.

Table 1. Parameter conditions of the samples.

\begin{tabular}{|c|c|c|c|c|c|c|c|}
\hline \multirow{2}{*}{$\begin{array}{l}\text { Sample } \\
\text { No. }\end{array}$} & \multirow{2}{*}{$\begin{array}{c}\text { Total weight } \\
(\mathrm{kg})\end{array}$} & \multirow{2}{*}{$\begin{array}{c}\text { Ratio } \\
\text { (Sludge/Waste) }\end{array}$} & \multirow{2}{*}{$\begin{array}{l}\text { Sludge } \\
(\mathrm{kg})\end{array}$} & \multirow{2}{*}{$\begin{array}{c}\text { Waste } \\
(\mathrm{kg})\end{array}$} & \multicolumn{2}{|c|}{ Moisture Content (\%) } & \multirow{2}{*}{$\mathrm{pH}$} \\
\hline & & & & & Sludge & Waste & \\
\hline I & 10 & $1: 2$ & 3.34 & 6.66 & & & 6.23 \\
\hline II & 10 & $2: 1$ & 6.66 & 3.34 & & & 6.76 \\
\hline III & 10 & $1: 1$ & 5.0 & 5.0 & 57.0 & 40.0 & 6.51 \\
\hline IV & 10 & Only OW ${ }^{\mathrm{a}}$ & - & 10.0 & & & 6.01 \\
\hline $\mathrm{V}$ & 10 & Only SS ${ }^{\mathrm{b}}$ & 10.0 & - & & & 7.13 \\
\hline
\end{tabular}

${ }^{\mathrm{a}} \mathrm{OW}$ : Organic waste, ${ }^{\mathrm{b} S S}$ : Sewage sludge.

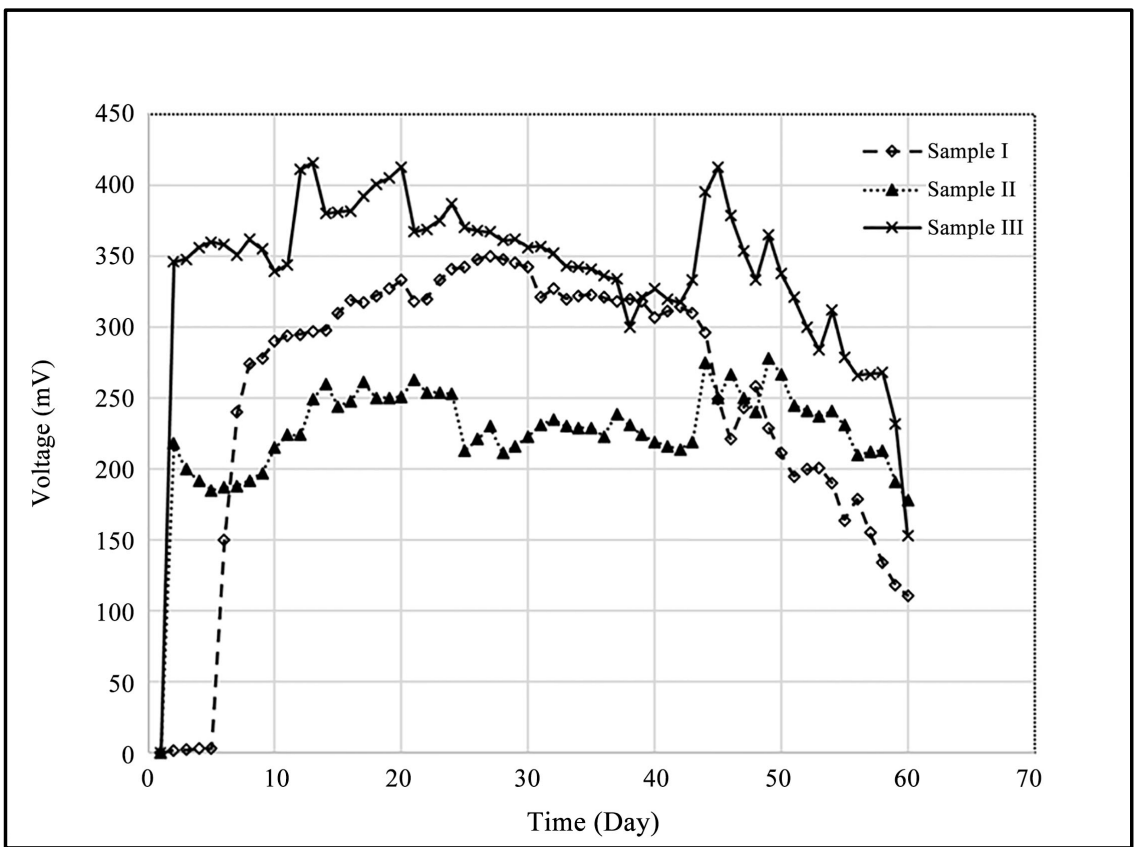

Figure 4. Variation of Voltage Output with time in MFC using mixed samples. 
The upraising of voltage generation was relatively lower than other sample cells, but the generation rate was more stable to apply it in actual usage. The voltage decreased gradually with time as the supply of organic waste and sewage sludge were degraded and used by the microbes. In anaerobic condition with the total weight of the sample mixture $10 \mathrm{~kg}$, at its 60th day, the final output of voltage was $178 \mathrm{mV}$. This voltage variation reading was taken over 60 days until it stopped showing a minimum output of voltage. However, the voltage did not increase more after the 21th day because of the bacterial activity decreased for the shortage of food.

The sample III produces a fair amount of voltage yield though the total amount of waste is less than any other samples. In this cell also, the voltage generation were increased sharply within the second day of the operation of the microbial fuel cell. It increased gradually and peaked after 13th days. The voltage decreased gradually with time as the supply of organic waste and sewage sludge were degraded and used by the microbes. Peak voltage was around $416 \mathrm{mV}$ using the ratio 1:1 of sewage sludge and organic waste in anaerobic condition and the total weight of the mixture was same as sample I and sample II. This voltage variation reading was taken until it stopped showing a minimum of output of voltage. However, voltage did not increase after the 53th day because of the bacterial activity was decreased for the shortage of food.

\subsection{Bioelectricity from Pure Samples}

In sample IV, the experiment was conducted only with the organic solid wastes to observe the variation of voltage generation than other MFCs with the time which is shown in Figure 5. Organic waste sample had moisture content of $40 \%$ with no admixture of sewage sludge. Only a total of $10 \mathrm{~kg}$ organic waste used to ensure the volume equivalent level of the designed MFC with this sample. For sample IV, the peak voltage was measured $918 \mathrm{mV}$ at only 2nd day of MFC's operation. This cell observation continued for 60 days and the final voltage gained of $243 \mathrm{mV}$. Strick et al. (2008) have found maximum voltage output around $250 \mathrm{mV}$ using plant microbial fuel cells (PMFCs) with Glyceria maxima. On the other hand, Khare and Bundela (2014) [15] reported $350 \mathrm{mV}$ voltage using waste water from food industries. In contrast with above two results, the maximum voltage generation was recorded from in this study using only kitchen wastes in a one-chamber MFC.

In Figure 5, sample $\mathrm{V}$ contained pure sewage sludge to observe the variation of voltage generation with the time. $10 \mathrm{~kg}$ of sewage sludge were used, and the highest moisture content prevailed of 57\%. From the second day, the voltage generation was high; but within the time, the voltage output decreased gradually like sample IV. Jati (2001) [16] and Hamzah (1983) [17] reported due to the presence of nutrients sewage sludge which supports the growth of microorganisms and accelerate the electricity production in very short time. But it lowered from $794 \mathrm{mV}$ to $625 \mathrm{mV}$ ( 2 - 7 days). For sharp lowering of the voltages, made 
the sustainability of the electricity generation disrupted in first week but within second week there's observed a stable output of voltage. This sample showed much higher values of voltage generation compared with the other four samples. This way shows us an effective solution to manage the vast nutrient rich sewage sludge from the commercial and industrial areas and convert it constantly something beneficial to the human kind. In addition, the use of these sewage sludge helps from the drainage problems in urban areas also. However, using only the sewage sludge and the peak voltage gained $960 \mathrm{mV}$ at the 13th day from the microbial fuel cell. The final voltage of this cell was also plentiful which presented $590 \mathrm{mV}$ voltage output at 60th day. The microorganism's activity with sewage sludge will produce a high voltage for long term.

\subsection{Relationship between Voltage Output and Current Density}

Always there is definite relationship between voltage output and current density. Figure 6 represents the relationship between voltage generation current in the MFCs at the 2nd week of operation. It shows that the relationship is almost linear. This linear curve indicates how stable the MFCs continue voltage generation as a function of current production with time [18] and the relationship stated that a stable voltage generation. The electromotive force of sample IV and sample $\mathrm{V}$ were $707 \mathrm{mV}$ and $960 \mathrm{mV}$ respectively. In contrast, the maximum power output of sample I, sample II and sample III were $298 \mathrm{mV}, 260 \mathrm{mV}$ and $416 \mathrm{mV}$. These values indicate that mixed samples voltage production rate was initially low whereas the rate for pure samples was high at initial stage.

\subsection{Effect of Mixing Ratio on Voltage Generation}

Sewage sludge and organic wastes were mixed with a ratio of the same volume to produce bioelectricity in a one chambered microbial fuel cell (MFC) under anaerobic condition. Table 2 clearly stated that sample $\mathrm{V}$ containing only sludge material shows the highest voltage at every day's voltage measurement. It means sewage sludge has the potential for bioelectricity production as a resource recovery option. Green energy production is presented as one of the ways of fulfilling alternative fuel demands of the future and to overcome the global energy crisis [18]. Similarly, sample IV had a sustaining voltage from 1st week to 6th week after sample V. And other samples voltage generation was low and stable. From the sample I, II and III, it shows that co-digestion of organic waste and sewage sludge produce less amount of voltage and more production days required for microbial activity.

\subsection{Effect of Anaerobic Co-Digestion}

In this study authors investigate anaerobic co-digestion of organic waste and sewage sludge in MFCs as a potential source of bio-electricity and found significant amount voltage output. Moqsud et al. (2013) [18] reported MFCs under anaerobic condition of organic waste can generate electricity and they found 


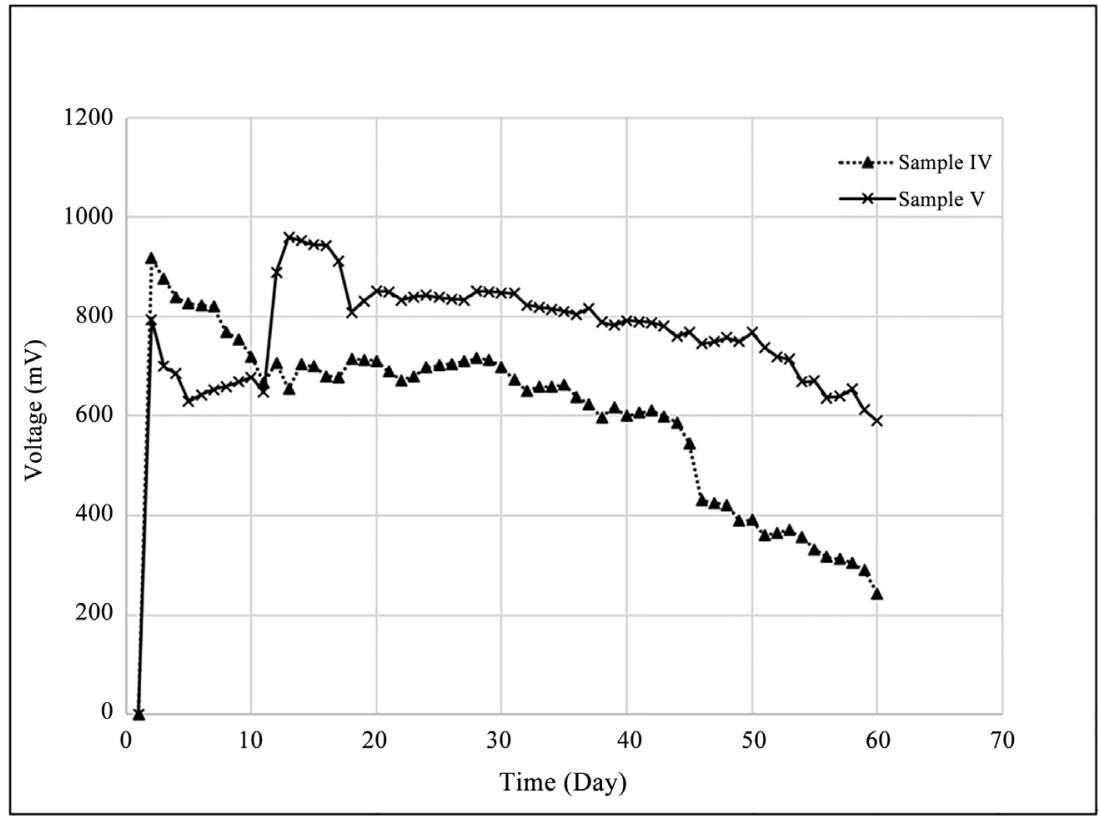

Figure 5. Variation of Voltage Output with time in MFC using pure samples.

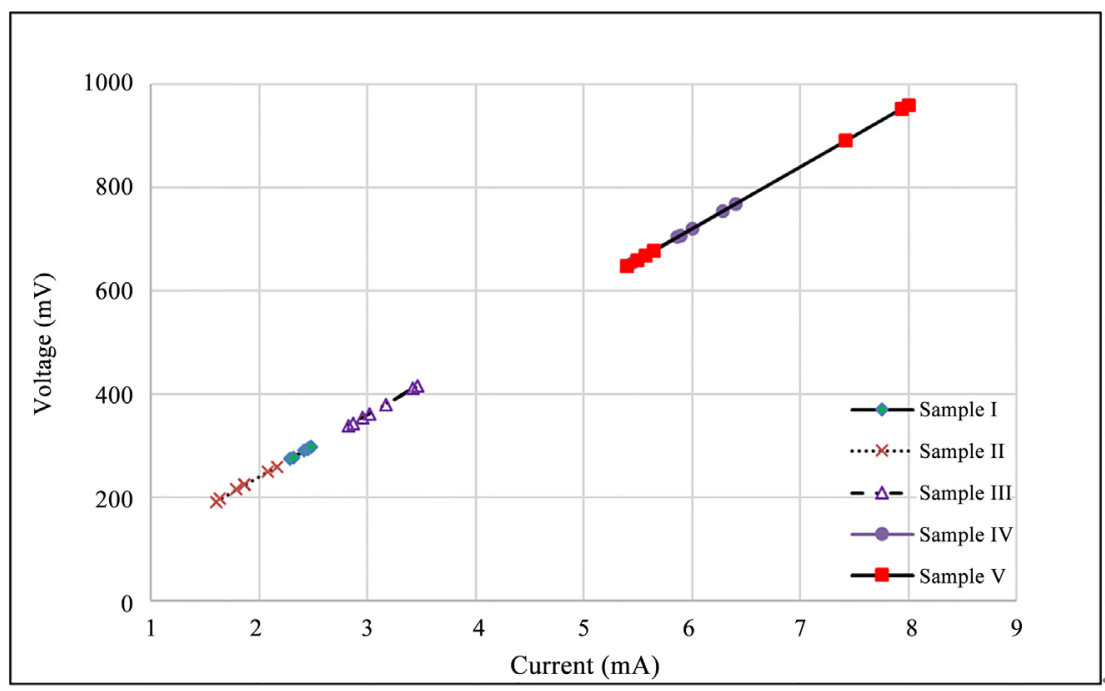

Figure 6. Relationship between voltage output and current density in the MFCs at 2nd week.

Table 2. Comparison of voltage generation rate.

\begin{tabular}{cccccc}
\hline Sample No. & $\begin{array}{c}\text { Ratio } \\
\text { (Sludge/Waste) }\end{array}$ & $\begin{array}{c}\text { Initial voltage } \\
(\mathrm{mV})\end{array}$ at $\mathbf{2}^{\text {nd }}$ day & $\begin{array}{c}\text { Peak voltage } \\
(\mathrm{mV})\end{array}$ & $\begin{array}{c}\text { Peak voltage } \\
\text { duration (day) }\end{array}$ & $\begin{array}{c}\text { Final voltage } \\
(\mathrm{mV})\end{array}$ at 60 days \\
\hline I & $1: 2$ & 2 & 350 & 27 & 111 \\
II & $2: 1$ & 218 & 263 & 21 & 178 \\
III & $1: 1$ & 346 & 416 & 13 & 153 \\
IV & Only OW $^{\text {a }}$ & 918 & 918 & 2 & 243 \\
V & Only SS $^{\mathrm{b}}$ & 794 & 960 & 13 & 590 \\
\hline
\end{tabular}

${ }^{\mathrm{a} O W}$ : Organic waste, ${ }^{\mathrm{b} S S}$ : Sewage sludge. 
around voltage $350 \mathrm{mV}$. However, in this work, using kitchen waste and sewage sludge in an anaerobic co-digestion cell found peak voltage $416 \mathrm{mV}$ for mixed sample and $960 \mathrm{mV}$ for pure sample. In the decomposition process, some gases were produced but it was not recorded due to lack of measuring instrument.

\section{Conclusions}

A one-chambered MFC using organic solid waste and sewage sludge can operate in anaerobic conditions and generate voltage to produce electricity were investigated in this research work.

- The experiment results show as organic waste and sewage sludge have a great potentiality to produce bioelectricity as for sample I, II and III the potential difference (voltage) peaked of $350 \mathrm{mV}, 263 \mathrm{mV}$ and $416 \mathrm{mV}$ respectively. On the other hand, sample IV covering only organic waste generated voltage 918 $\mathrm{mV}$ but the MFC with only sewage sludge showed peak $960 \mathrm{mV}$ which shows a high voltage rate than other cells over the same digestion period.

- Considering the availability any of the mixing ratio in anaerobic co-digestion, would be enough to generate electricity for small scale use. Two burning problems of modern world, energy depletion and waste management would be solved with this resource recovery option and replace the fossil fuels with safe and green energy. The slurry from the microbial fuel cell, can be used as the soil nutrient beneficial for stable organic matter to soil, increase soil structure, water infiltration and better yield from agricultural land.

The organic waste and sewage sludge can be utilized as a power generation source as well as compost production for using as an alternative soil conditioner. In this work, no additional micro-organism was used, but to achieve better microbial activity for longer run of the cell more artificial bacteria would be supplied. As the voltage generation is smaller even it can fulfill very few demands of millions of people who have no electricity supply.

\section{Acknowledgements}

The authors conform that there was no commercial interest or financial supports from others that could be construed as a potential conflict of interest.

\section{Conflicts of Interest}

The authors declare no conflicts of interest regarding the publication of this paper.

\section{References}

[1] Moqsud, M.A., Omine, K., Yasufuku, N., Bushra, Q.S., Hyodo, M. and Nakata, Y. (2014) Bioelectricity from Kitchen and Bamboo Waste in a Microbial Fuel Cell. Waste Management \& Research, 32, 124-130. https://doi.org/10.1177/0734242X13517160

[2] Gazali, T.A. and Moqsud, M.A. (2017) The Effectiveness of Animal Dungs and Leaf Mold for Bioelectricity Generation Using Microbial Fuel Cell with Soils. Journal of Sustainable Bioenergy Systems, 7, 165-181. https://doi.org/10.4236/jsbs.2017.74012 
[3] Moqsud, M.A. (2003) A Study on Composting of Solid Waste in Bangladesh. Master's Thesis, Bangladesh University of Engineering and Technology, Bangladesh.

[4] Zurbrugg, C., Drescher, S., Rytz. I., Sinha, A.M.M. and Enayettullah, I. (2005) Decentralized Composting in Bangladesh, a Win-Win Situation for All Stakeholders. Resources, Conservation and Recycling, 43, 281-292. https://doi.org/10.1016/j.resconrec.2004.06.005

[5] Sujauddin, M., Huda, S.M.S. and Hoque, R. (2008) Household Solid Waste Characteristics and Management in Chittagong, Bangladesh. Waste Management, 28, 1688-1695. https://doi.org/10.1016/j.wasman.2007.06.013

[6] Mostafa, R., Ali, A., Ghoreyshi, G.N. and Tahereh, J. (2011) Power Generation from Organic Substrate in Batch and Continuous Flow Microbial Fuel Cell Operations. Applied Energy, 88, 3999-4004. https://doi.org/10.1016/j.apenergy.2011.04.017

[7] Moqsud, M.A., Omine, K., Yasufuku, N., Hyodo, M. and Nakata, Y. (2013) Microbial Fuel Cell (MFC) for Bioelectricity Generation from Organic Wastes. Waste Management, 33, 2465-2469.

[8] Rosenbaum, M., He, Z. and Angenent, T.L. (2010) Light Energy to Bioelectricity: Photosynthetic Microbial Fuel Cells. Current Opinion in Biotechnology, 21, 259-264. https://doi.org/10.1016/j.copbio.2010.03.010

[9] Qiao, Y., Bao, S.-J. and Li, C.M. (2010) Electrocatalysis in Microbial Fuel Cells from Electrode Material to Direct Electrochemistry. Energy \& Environmental Science, 3, 544-553. https://doi.org/10.1039/b923503e

[10] Zupancic, D.G. and Grilc, V. (2012) Anaerobic Treatment and Biogas Production from Organic Waste. Institute for Environmental Protection and Sensors, Slovenia. http://cdn.intechopen.com/pdfs/27154/InTech-Anaerobic_treatment_and_biogas_p roduction_from_organic_waste.pdf

[11] Bennetto, H.P. (1984) Microbial Fuel Cells. Life Chemistry Reports, 2, 363-453.

[12] Kannaiah G.R., Suresh, B.P. and Venkata, M.S. (2011) Canteen Based Food Waste as Potential Anodic Fuel for Bioelectricity Generation in Single Chambered Microbial Fuel Cell (MFC): Bio-Electrochemical Evaluation under Increasing Substrate Loading Condition. International Journal of Hydrogen Energy, 36, 6210-6218. https://doi.org/10.1016/j.ijhydene.2011.02.056

[13] Mata-Alvarez, J., Mace, S. and Llabres, P. (2000) Anaerobic Digestion of Organic Solid Wastes. An Overview of Research Achievements and Perspectives. Bioresource Technology, 74, 3-16. https://doi.org/10.1016/S0960-8524(00)00023-7

[14] Quanguo, Z., Jianjun, H. and Du, J.L. (2016) Microbial Fuel Cells as Pollutant Treatment Units: Research Updates. Bio-Resource Technology, 217, 121-128. https://doi.org/10.1016/j.biortech.2016.02.006

[15] Jati, S.H. (2001) Pemanfataan Kompos DaunJatidan Mikrohizauntuk Pembibitan Jati. [Utilization of Teak Leaf Compost and Mycorrhiza for Teak Nursery.] Institut Pertanian Bogor, 7.

[16] Hamzah, Z. (1983) Diktat Ilmu Tanah. Pusat Pendidikan Kehutanan Cepu, Direksi Perum Perhutani. [Soil Science Textbook. Cepu Forest Education Center.]

[17] Moqsud, M.A., Yoshitake, J., Bushra, Q.S., Hyodo, M., Omine, K. and Strik, D. (2015) Compost in Plant Microbial Fuel Cell for Bioelectricity Generation. Waste Management, 36, 63-69. https://doi.org/10.1016/j.wasman.2014.11.004

[18] Moqsud, M.A., Omine, K., Hyodo, M., Nakata, Y. and Yoshitake, J. (2013) Study of Bioelectricity Generation by Using Compost in Paddy Plant Microbial Fuel Cell. Proceedings of the 28th International Conference on Solid Waste Technology and Management, Philadelphia, PA, 10-13 March 2013, 110-109. 